\begin{tabular}{ll}
\hline & $\begin{array}{l}\text { Thabiea : Journal of Natural Science Teaching } \\
\text { Program Studi Tadris Ilmu Pengetahuan Alam } \\
\text { Institut Agama Islam Negeri Kudus }\end{array}$ \\
$\begin{array}{l}\text { http://journal.stainkudus.ac.id/index.php/Thabiea } \\
\text { p-issn: } 25808474\end{array}$ \\
\hline
\end{tabular}

\title{
Ayo Belajar IPA dari Ulama: Pembelajaran Berbasis Socio-Scientific Issues
}

\section{di Abad ke-21}

Muhamad Imaduddin ${ }^{\mathrm{a}, 1^{*}, Z^{2} \text { aenal Khafidin }}{ }^{\mathrm{a}, 2}$

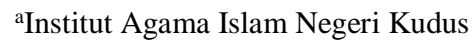

*11imad@stainkudus.ac.id; 2Zaenal.khafidin@gmail.com

\begin{tabular}{l}
\hline Kata kunci: \\
\hline Fatwa MUI \\
Media \\
Pembelajaran \\
IPA \\
Socio-Scientific \\
Issues \\
Keterampilan \\
Abad $\mathrm{Ke}-21$
\end{tabular}

\section{ABSTRAK}

Perubahan mindset pendidik IPA harus didasarkan pada keterampilan apa saja yang dibutuhkan peserta didik agar mencapai partisipasi penuh di masyarakat. Salah satu strategi potensial adalah pembelajaran berbasis Socio-Scientific Issues (SSI). Sejalan dengan isu-isu yang berkembang, Fatwa MUI hadir sebagai keputusan yang diberikan oleh ulama-ulama tentang permasalahan umat Islam didasarkan Al-Qur'an, Hadis, Ijma', Qiyas, dan dalil lain yang muktabar. Implementasi media Fatwa MUI adalah wujud Islamisasi sains yang mengarah pada bagaimana sains dapat meningkatkan iman dan taqwa. Kajian ini bertujuan mengungkap Fatwa MUI apa saja yang dapat digunakan sebagai media pembelajaran IPA, serta bagaimana implementasinya. Metode library research digunakan melalui penggalian informasi Kompetensi Inti (KI) dan Kompetensi Dasar (KD) pada struktur kurikulum IPA, serta kumpulan fatwa MUI. Hasil menunjukkan bahwa terdapat beberapa KD yang dapat dikaitkan dengan Fatwa MUI seperti zat aditif, zat adiktif-psikotropika, dan pencemaran lingkungan. Implementasi dapat dilakukan dengan desain pembelajaran bervisi SETS (Science-Environment-Technology-Society) dan berpondasi aspek Islami. Domain kognitif, afektif, dan budaya sosial dalam keterampilan abad ke-21 dapat ditumbuhkan seiring dengan tumbuhnya domain spiritual. Implikasi mengarah pada uji coba desain pembelajaran berbasis SSI dengan Fatwa MUI bidang POM, IPTEK dan lingkungan.

\begin{tabular}{l}
\hline Key word: \\
\hline MUI Fatwa, \\
Science Learning \\
Media \\
Socio-Scientific Issues \\
$21^{\text {st }}$ Century Skills
\end{tabular}

\section{ABSTRACT}

The changes of science educators' mindset must be based on what skills are needed by student for achieving full participation in society. One potential strategy is SocioScientific Issues (SSI) based learning. In line with the growing issues, the MUI Fatwa is present as decisions given by ulama about the Muslims' problems based on AlQur'an, Hadith, Ijma', Qiyas, and other reputable propositions. Implementation of MUI fatwa media as Islamization of science leads to how science can increase faith and taqwa. This study aims to reveal any MUI fatwa which can be used as science learning media, and how to implement. The library research is used through extracting of Core and Basic Competence on science curriculum, and MUI fatwa body. The results show that there are several competences can be associated with MUI fatwa such as additives, addictive-psychotropic substances, and environmental pollution. It can be implemented with SETS (Science-Environment-TechnologySociety) learning design based on Islamic aspect. Cognitive, affective, and socialcultural domains in 21st Century Skills can be grown in tandem with the growth of spiritual domain. The implication leads to experimental design of SSI-based instruction with MUI fatwa in the field of Drug and Food Supervision, Science and Technology, as well as environment.

Copyright $\odot 2018$ Institut Agama Islam Negeri Kudus. All Right Reserved 


\section{Pendahuluan}

Seiring dengan perkembangan ilmu pengetahuan dan teknologi yang ada di abad ke21 , telah terjadi pergeseran baik ciri maupun model pembelajaran. Hal inilah yang diantisipasi melaui kehadiran kurikulum nasional yang diterapkan di Indonesia. Dalam kurikulum nasional, mata pelajaran IPA di tingkat SMP/MTs dikemas secara terintegrasi pada keilmuan IPA yang meliputi: fisika, biologi, kimia, serta ilmu pengetahuan bumi dan antariksa. Selain itu, National Science Teachers Association juga merekomendasikan agar guru-guru IPA pada level sekolah dasar dan menengah harus memiliki kemampuan mengembangkan pembelajaran IPA yang tematik, terpadu dan interdisipliner (National Science Teachers Association, 2003, p. 8). Perubahan mindset para pendidik harus didasarkan pada kecakapan apa saja yang nantinya dibutuhkan oleh para peserta didik untuk dapat mencapai partisipasi penuh di masyarakat di abad ke-21.

Sejalan dengan perkembangan zaman, berbagai permasalahan yang ada di masyarakat semakin beragam dan kompleks. Peserta didik yang merupakan bagian dari masyarakat diharapkan peka dan mampu memberikan respon pada level-level tertentu sesuai dengan keterampilan yang dimilikinya. Sains atau IPA sebagai salah satu mata pelajaran yang diberikan secara formal di sekolah mengarah pada pembekalan keterampilan abad ke-21 yang meliputi domain kognitif, afektif, dan budaya sosial (Kang, Heo, Jo, Shin, \& Seo, 2010). Partnership for 21 st Century skills (P21) mengklasifikasikan keterampilan abad ke-21 yang seharusnya dimiliki oleh peserta didik sebagai "Keterampilan Belajar dan Inovasi (Learning and Innovation Skills)", "Keterampilan Hidup dan Karir (Life and Career Skills)", dan "Keterampilan Media dan Teknologi Informasi (Information Media and Technology Skills)" (Partnership for $21^{\text {st }}$ Century Learning, 2015). Setiap peserta didik diharapkan memiliki kemampuan berpikir kreatif dan pemecahan masalah yang dibutuhkan untuk partisipasi aktif individu di masyarakat dan tempat kerjanya di masa mendatang. Bagi peserta didik, "keberhasilan" dalam menempuh pendidikan adalah penguasaan keterampilan abad ke-21 ini pada usia sangat dini (Louis, 2012). Konsekuensi tersebut memberikan orientasi konsep moral ilmu pada pengembangan kurikulum mata pelajaran IPA sebagai ilmu yang bermanfaat (useful knowledge). Sejalan dengan pandangan Islam, yang dimaksudkan ilmu yang bermanfaat adalah ilmu yang membawa kebaikan bagi diri dan orang lain tidak hanya dalam kehidupan dunia, tetapi juga akhirat (Golshani, 2004).

Kebermanfaatan ilmu yang dimiliki peserta didik dapat dilihat dari kemampuan peserta didik dalam memberikan sumbangan pemikiran dan solusi terhadap berbagai permasalahan yang ada di masyarakat. Salah satu strategi pembelajaran yang potensial terkait dengan proses pemecahan masalah tersebut adalah strategi pembelajaran berbasis Sosio-Scientific Issues (SSI). SSI adalah strategi yang bertujuan untuk menstimulasi perkembangan intelektual, moral dan etika, serta kesadaran perihal hubungan antara sains dengan kehidupan sosial (Nuangchalerm, 2009; Zeidler, Sadler, Simmons, \& Howes, 2005). SSI merupakan representasi isu-isu atau persoalan dalam kehidupan sosial yang secara konseptual berkaitan erat dengan sains (Anagün \& Özden, 2010) dan solusi jawaban yang relatif atau tidak pasti (Topcu, Sadler, \& Yilmaz-Tuzun, 2010).

Isu-isu yang berkembang dalam pembelajaran berbasis SSI dapat secara langsung maupun tidak langsung berkaitan dengan aspek keagamaan (Islam). Hal ini dikarenakan keberadaan masyarakat Indonesia yang memegang teguh nilai-nilai kegamaan yang dimilikinya. Terkait dengan permasalahan yang dihadapi oleh masyarakat muslim, Majelis Ulama Indonesia (MUI), yang telah berdiri sejak tahun 1975 , berperan sebagai pemberi fatwa bagi masyarakat yang membutuhkan. Permintaan fatwa bisa berasal dari ulil amri (pemerintah) bisa juga dari masyarakat luas. 
Permasalahan yang muncul untuk dimintakan fatwanya ke MUI pun sangat beragam, mulai dari masalah keseharian yang terkait dengan urusan pribadi hingga masalah kebijakan yang terkait dengan urusan politik dan sosial kemasyarakatan; mulai dari masalah halal haramnya makanan hingga masalah kedokteran serta perkembangan ilmu pengetahuan dan teknologi (Amin et al., 2015). Melihat berbagai permasalahan yang berkaitan dengan fatwa MUI, menjadi menarik untuk dikaji potensi fatwa tersebut sebagai alternatif media pembelajaran IPA berbasis SSI. Pemanfaatan media fatwa MUI dalam pembelajaran akan memberikan nuansa Islamisasi sains pada mata pelajaran IPA. Dalam konteks Kurikulum Nasional, adanya hubungan antara sains dan agama tersebut diwujudkan pada Kompetensi Inti (KI) yang pertama.

Kompetensi Inti dirancang dalam empat kelompok yang saling terkait (Badan Penelitian dan Pengembangan, 2013, p. 5), yaitu berkenaan dengan sikap keagamaan (kompetensi inti 1), sikap sosial (kompetensi 2), pengetahuan (kompetensi inti 3), dan penerapan pengetahuan (kompetensi 4). Keempat kelompok itu menjadi acuan dari Kompetensi Dasar (KD) dan harus dikembangkan dalam setiap peristiwa pembelajaran secara integratif. Kompetensi yang berkenaan dengan sikap keagamaan dan sosial dikembangkan secara tidak langsung (indirect teaching) yaitu pada waktu peserta didik belajar tentang pengetahuan (kompetensi kelompok 3) dan penerapan pengetahuan (Kompetensi Inti kelompok 4). Dengan demikian, melalui pembelajaran IPA yang berbasis SSI dengan perspektif pemikiran Ulama, peserta didik juga dapat lebih mengenal ajaran Islam dalam menyelesaikan permasalahan di masyarakat. Kajian ini akan mengulas lebih lanjut Fatwa MUI apa saja yang dapat dijadikan sebagai alternatif pembelajaran IPA sesuai Kompetensi Dasar (KD) pada jenjang SMP/MTs, serta bagaimana desain implementasinya pada pembelajaran.

\section{Metode}

Kajian ini menggunakan pendekatan kualitatif dengan jenis studi pustaka (library research). Pendekatan kualitatif merupakan prosedur yang menghasilkan data deskriptif berupa kata-kata (ucapan), tulisan, dan perilaku dari orang-orang yang dapat diamati. Pendekatan ini digunakan untuk mendesain pembelajaran berbasis Socio-scientific Issues (SSI) dengan menganalisis dokumen-dokumen terkait dengan kurikulum IPA Terpadu yang ada di SMP/MTs yang diterbitkan oleh Kementerian Pendidikan dan Kebudayaan (2013), himpunan fatwa MUI, serta visi SETS dan implementasi kurikulumnya. Sesuai dengan jenis sumber data yang bertumpu pada data dokumenter, maka pengumpulan data dalam studi ini menggunakan metode dokumentasi. Analisis data dilakukan dengan menggunakan metode analisis dokumen (document analysis). Hasil desain yang dibuat diverivikasi melalui analisis konten dan kesesuainnya dengan Kurikulum Nasional jenjang SMP/MTs pada mata pelajaran IPA.

\section{Hasil}

\section{Potensi Fatwa MUI sebagai Media Pembelajaran Berbasis SSI}

Kemajuan dalam bidang ilmu pengetahuan dan teknologi serta perkembangan tatanan sosial kemasyarakatan, budaya, politik dan ekonomi akhir-akhir ini telah sampai pada seluruh aspek kehidupan. Perkembangan dan perubahan zaman tersebut tidak saja membawa berbagai kemudahan dan kebahagiaan, namun juga telah menimbulkan sejumlah perilaku dan persoalan baru. Cukup banyak persoalan yang sebelumnya tidak dikenal dan terpikirkan, dan kini menjadi kenyataan. Di sisi lain, kesadaran keberagamaan umat Islam di Indonesia semakin berkembang. Oleh karena itu, jika menghadapi permasalah, menjadi penting bagi Muslim untuk memperoleh jawaban dari sudut pandang ajaran Islam. Majelis Ulama Indonesia (MUI), wadah musyawarah para ulama, zu'ama dan 
cendikiawan muslim adalah lembaga yang kompeten dalam menjawab dan memecahkan setiap permasalahan sosial kegamaan yang dihadapi oleh masyarakat.

Majelis Ulama Indonesia (MUI) berwenang menetapkan fatwa mengenai masalah-masalah syariah secara umum, baik dalam bidang akidah, ibadah, maupun akhlak dengan senantiasa menjunjung tinggi asas kebenaran dan kemurnian pengalaman agama oleh umat Islam di Indonesia. Kewenangan penetapan fatwa meliputi faham keagamaan yang muncul di masyarakat, masalah sosial kemasyarakatan, masalah pangan, obat-obatan dan kosmetika (POM), masalah yang terkait dengan perkembangan ilmu pengetahuan dan teknologi, serta masalah ekonomi syari'ah (Amin et al., 2015). Merujuk pada hal tersebut, area pembelajaran IPA berkaitan dengan permasalahan POM dan IPTEK yang berkembang di masyarakat. Dengan demikian, potensi Fatwa MUI yang dapat dijadikan sebagai media pembelajaran berbasis SSI berada pada area tersebut.

Didasarkan Kompetensi Dasar (KD) yang ada pada struktur kurikulum SMP/MTs, dapat dianalisis potensi kesesuaian tema isu yang berhubungan dengan fatwa MUI untuk dijadikan unifying concept atau konsep pemersatu. Konsep pemersatu ini dapat dilihat sebagai konsep yang menyatukan beberapa KD ataupun konsep yang menyatukan keilmuan biologi, fisika, kimia, serta ilmu pengetahuan bumi dan antariksa (IPBA). Biologi merupakan ilmu pengetahuan yang mempelajari makhluk hidup dan gejala-gejalanya, sedangkan fisika adalah ilmu pengetahuan yang mempelajari benda tidak hidup dari aspek wujud dengan perubahan-perubahan yang besifat sementara. Adapun kimia mengkaji mengenai makhluk hidup dan benda tak hidup dari aspek susunan materi dan perubahan-perubahan yang bersifat tetap, sementara IPBA membahas bumi sebagai salah satu anggota tata surya dan ruang angksa dengan benda angkasa lainnya (Jasin, 2013).

Dengan mengkaji struktur kurikulum IPA SMP/MTs melalui interpretasi dan analisis Kompetensi Dasar (KD), serta melihat pada Himpunan Fatwa MUI bidang POM dan IPTEK, dapat dirangkum potensi isu-isu yang dapat diangkat pada pembelajaran berbasis SSI sebagaimana disajikan pada Tabel 1, Tabel 2, dan Tabel 3. Kompetensi Dasar yang dikaji adalah KD yang diturunkan dari Kompetensi Inti ketiga (KI 3) yang berkaitan dengan aspek pengetahuan yaitu "memahami dan menerapkan pengetahuan (faktual, konseptual, dan prosedural) berdasarkan rasa ingin tahunya tentang ilmu pengetahuan, teknologi, seni, budaya terkait fenomena dan kejadian tampak mata". 
Tabel 1 Analisis Kompetensi Dasar (KD) IPA kelas VII SMP/MTs dan Potensi Isu sesuai dengan Fatwa MUI untuk Pembelajaran Berbasis SSI

\begin{tabular}{|c|c|}
\hline Kode & Kompetensi Dasar \\
\hline 3.1. & $\begin{array}{l}\text { Memahami konsep pengukuran berbagai besaran yang ada pada } \\
\text { diri, makhluk hidup, dan lingkungan fisik sekitar sebagai bagian } \\
\text { dari observasi, serta pentingnya perumusan satuan terstandar } \\
\text { (baku) dalam pengukuran }\end{array}$ \\
\hline 3.2 . & $\begin{array}{l}\text { Mengidentifikasi ciri hidup dan tak hidup dari benda-benda dan } \\
\text { makhluk hidup yang ada di lingkungan sekitar }\end{array}$ \\
\hline 3.3 . & $\begin{array}{l}\text { Memahami prosedur pengklasifikasian makhluk hidup dan } \\
\text { benda-benda tak-hidup sebagai bagian kerja ilmiah,serta } \\
\text { mengklasifikasikan berbagai makhluk hidup dan benda-benda } \\
\text { tak-hidup berdasarkan ciri yang diamati }\end{array}$ \\
\hline 3.4 . & $\begin{array}{l}\text { Mendeskripsikan keragaman pada sistem organisasi kehidupan } \\
\text { mulai dari tingkat sel sampai organisme, serta komposisi bahan } \\
\text { kimia utama penyusun sel }\end{array}$ \\
\hline 3.5 . & $\begin{array}{l}\text { Memahami karakteristik zat, serta perubahan fisika dan kimia } \\
\text { pada zat yang dapat dimanfaatkan untuk kehidupan sehari-hari } \\
\text { (misalnya pemisahan campuran) }\end{array}$ \\
\hline
\end{tabular}

3.6. Mengenal konsep energi, berbagai sumber energi, energi dari makanan, transformasi energi dalam sel, metabolisme sel, respirasi, sistem pencernaan makanan, dan fotosintesis

3.7. Memahami konsep suhu, pemuaian, kalor, perpindahan kalor,dan penerapannya dalam mekanisme menjaga kestabilan suhu tubuh pada manusia dan hewan serta dalam kehidupan sehari-hari

3.8. Mendeskripsikan interaksi antar makhluk hidup dan lingkungannya

3.9. Mendeskripsikan pencemaran dan dampaknya bagi makhluk hidup

3.10 Mendeskripsikan tentang penyebab terjadinya pemanasan global dan dampaknya bagi ekosistem
Isu sesuai dengan Fatwa MUI

Fatwa MUI Nomor: 02 Tahun 2010 tentang Air Daur Ulang $\rightarrow$ dikaitkan dengan konsep Volume air dua kullah

1) Fatwa MUI Nomor 11 Tahun 2009 tentang Hukum Alkohol (tanggal 18 November 2009) $\rightarrow$ dikaitkan dengan proses fermentasi

2) Fatwa MUI Nomor 10 Tahun 2011 tentang Cara Penyucian Ekstrak Ragi (Yeast Extract) dari Sisa Pengolahan Bir (Brewer Yeast), tanggal 3 Maret 2011

Membahas tentang Burung Walet dikaitkan dengan Fatwa MUI Nomor 02 Tahun 2012 tentang Sarang Burung Walet (tanggal 12 Januari 2012)

1) Fatwa MUI No 41/2014 tentang Pengelolaan Sampah untuk Pencegahan Kerusakan Lingkungan (tanggal 07 November 2014);

2) Fatwa MUI No 4/2014 tentang Pelestarian Satwa Langka untuk Keseimbangan Ekosistem (tanggal 22 Januari 2014).

3) Fatwa MUI Nomor 30 Tahun 2016 tentang Hukum Pembakaran Hutan dan Lahan serta Pengendaliannya (27 Juli 2016) 
Tabel 2 Analisis Kompetensi Dasar (KD) IPA kelas VIII SMP/MTs dan Potensi Isu sesuai dengan Fatwa MUI untuk Pembelajaran Berbasis SSI

\begin{tabular}{ll}
\hline Kode & Kompetensi Dasar \\
\hline 3.1. & $\begin{array}{l}\text { Memahami gerak lurus, pengaruh gaya terhadap gerak, } \\
\text { serta penerapannya pada gerak makhluk hidup dan gerak } \\
\text { benda dalam kehidupan sehari-hari }\end{array}$ \\
3.2. & $\begin{array}{l}\text { Mendeskripsikan kegunaan pesawat sederhana dalam } \\
\text { kehidupan sehari-hari serta pada sistem rangka manusia } \\
\text { dan hewan }\end{array}$
\end{tabular}

3.3. Mendeskripsikan tentang sifat material dan konsep gaya yang digunakan dalam konstruksi bangunan, serta pengaruh material tertentu terhadap kesehatan manusia

3.4. Memahami sifat fluida dan menerapkannya untuk menjelaskan transportasi darah dalam sistem peredaran darah serta transportasi cairan pada tumbuhan, tekanan osmosis, difusi pada peristiwa respirasi serta penerapan dalam kehidupan sehari-hari

3.5. Memahami konsep getaran, gelombang, bunyi, dan pendengaran, serta penerapannya dalam sistem sonar pada hewan dan dalam kehidupan sehari-hari

3.6. Mendeskripsikan sifat-sifat cahaya, pembentukan bayangan, serta aplikasinya untuk menjelaskan penglihatan manusia, struktur mata pada hewan, dan prinsip kerja alat optic

3.7. Menjelaskan keterkaitan struktur jaringan tumbuhan dan fungsinya, serta berbagai pemanfaatannya dalam teknologi yang terilhami oleh struktur tersebut

3.8. Mendeskripsikan sistem pencernaan serta keterkaitannya dengan sistem pernapasan, sistem peredaran darah, dan penggunaan energi makanan

3.9. Mengenal konsep listrik statis, potensial listrik, hantaran listrik, kelistrikan pada sistem syaraf, kelistrikan pada jantung, kelistrikan tulang, dan hewan-hewan yang mengandung listrik

3.10 Mendeskripsikan zat aditif (alami dan buatan) dalam makanan dan minuman (segar dan dalam kemasan), dan zat adiktif-psikotropika serta pengaruhnya terhadap kesehatan
Isu sesuai dengan Fatwa MUI

Keputusan komisi Fatwa MUI DKI Jakarta tentang hukum donor darah bagi orang yang sedang berpuasa (tanggal 24 Juli 2000)

Fatwa MUI tentang Wasiat Menghibahkan Kornea Mata (tanggal 13 Juni 1979)

Fatwa MUI Nomor: 07 Tahun 2010 tentang Kopi Luwak (tanggal 20 Juli 2010) $\rightarrow$ dikaitkan dengan struktur jaringan pada biji kopi.

1) Fatwa MUI tentang Memakan Daging Kelinci (tanggal 12 Maret $1983 \rightarrow$ berkaitan dengan upaya pemerintah dalam perbaikan gizi keluarga)

2) Fatwa MUI tentang Makanan dan Minuman yang Bercampur dengan Najis (tanggal 01 Juni 1980)

1) Fatwa MUI tentang Produk Penyedap Rasa (Monosodium Glutamate, MSG) dari PT. Ajinomoto Indonesia yang menggunakan Bacto Soynote (tanggal 16 Desember 2000)

2) Fatwa MUI tentang Produk Penyedap Rasa (Monosodium Glutamate, MSG) dari PT.

Ajinomoto Indonesia yang menggunakan mameno (tanggal 19 Februari 2001)

3) Fatwa MUI Nomor: 43 Tahun 2012 tentang Penyalahgunaan Formalin dan Bahan Berbahaya Lainnya dalam Penanganan dan 
4) Fatwa MUI Nomor : 33 Tahun 2011 tentang HUKUM Pewarna Makanan Dan Minuman Dari Serangga Cochineal (tanggal 10 Agustus 2011)

5) Fatwa MUI tentang Penyalahgunaan Ekstaksi dan Zat-zat Jenis Lainnya (tanggal 2 September 1996)

3.11 Memahami reproduksi pada tumbuhan, hewan, dan manusia, sifat keturunan, serta kelangsungan makhluk hidup

3.12 Mendeskripsikan penyebab perkembangan penduduk dan dampaknya bagi lingkungan

1) Fatwa MUI Nomor: Kep139/MUI/IV/2000 tentang Makan dan Budi Daya Cacing dan Jangkrik (tanggal 18 April 2000)

2) Fatwa MUI tentang Memakan dan Membudidayakan Kodok (tanggal 12 November 1984)

1) Fatwa MUI Nomor: 3/MUNAS VI/MUI/2000 tentang Kloning, tanggal 29 Juli 2000

2) Fatwa Nomor: 06 Tahun 2010 tentang Vaksin Meningitis bagi Jemaah Haji atau Umroh, tanggal 16 Jui 2010

3) Fatwa MUI Nomor: 04 Tahun 2016 tentang Imunisasi (tanggal 23 Januari 2016)

3.13 Memahami struktur bumi untuk menjelaskan fenomena gempa bumi dan gunung api, serta kaitannya dengan keragaman batuan dan mineral di beberapa daerah

3.14 Mendeskripsikan karakteristik matahari, bumi, bulan, planet, benda angkasa lainnya dalam ukuran, struktur, gaya gravitasi, orbit, dan gerakannya, serta pengaruh radiasi matahari terhadap kehidupan di bumi

3.15 Mendeskripsikan gerakan bumi dan bulan terhadap matahari serta menjelaskan perubahan siang dan malam, peristiwa gerhana matahari dan gerhana bulan, perubahan musim serta dampaknya bagi kehidupan di bumi 
Tabel 3 Analisis Kompetensi Dasar (KD) IPA kelas IX SMP/MTs dan Potensi Isu sesuai dengan Fatwa MUI untuk Pembelajaran Berbasis SSI

\begin{tabular}{ll}
\hline Kode & Kompetensi Dasar \\
\hline 3.1. & $\begin{array}{l}\text { Mendeskripsikan struktur rangka dan otot manusia, serta } \\
\text { prinsip keseimbangan dan gaya statik dalam menjalankan }\end{array}$ \\
& $\begin{array}{l}\text { fungsinya pada berbagai kondisi } \\
\text { 3.2. }\end{array}$ \\
& $\begin{array}{l}\text { Menjelaskan struktur dan fungsi sistem eksresi pada } \\
\text { manusia dan penerapanya dalam menjaga kesehatan diri }\end{array}$
\end{tabular}

3.3. Mendeskripsikan struktur dan fungsi sistem reproduksi pada manusia, kelainan dan penyakit pada sistem reproduksi, dan dampak negatif hubungan badan pranikah serta pencegahanya

Isu sesuai dengan Fatwa MUI

1) Fatwa MUI tentang Pengambilan dan Penggunaan Katup Jantung, tanggal 29 Juni 1979

2) Fatwa MUI Nomor: 2/MUNAS VI/MUI/2000 tentang Penggunaan Organ Tubuh, Ari-ari, dan Air Seni Manusia bagi Kepentingan Obatobatan dan Kosmetika

1) Fatwa MUI tentang Vasektomi dan Tubektomi (tanggal 13 Juli 1977)

2) Fatwa MUI tentang Bayi Tabung/Inseminasi Buatan (tanggal 13 Juni 1979)

3) Fatwa MUI tentang Operasi Perubahan/Penyempurnaan Kelamin (tanggal 01 Juni 1980)

4) Fatwa MUI Nomor: 28 tahun 2013 tentang seputar masalah donor air susu ibu (istirdla'), tanggal 13 Juli 2013

3.4. Memahami konsep atom dan partikel penyusunnya, ion dan molekul, serta hubungannya dengan karakteristik material yang digunakan dalam kehidupan sehari-hari

3.5. Mendeskripsikan karakteristik rangkaian listrik, transmisi energi listrik, sumber-sumber energi listrik alternatif (termasuk bioenergi), berbagai upaya dalam menghemat energi listrik, serta serta teknologi listrik yang digunakan dalam elektrokardiografi (EKG) dan alat bantu pendengaran

3.6. Mendeskripsikan konsep medan listrik, medan magnet, induksi elektromagnetik,dan penggunaannya dalam produk teknologi, serta pemanfaatan medan listrik dan magnet dalam pergerakan/navigasi hewan untuk mencari makanan dan migrasi

3.7. Mendeskripsikan cara kerja laser dan peralatan difraksi sinar-X serta pemanfaatannya untuk perawatan kesehatan

3.8. Mengidentifikasi proses dan hasil pewarisan sifat serta penerapannya dalam pemuliaan mahluk hidup

3.9. Menyajikan data dan laporan penerapan bioteknologi dalam mendukung kelangsungan hidup manusia melalui produksi pangan

3.10 Membedakan proses dan produk teknologi yang merusak lingkungan dan ramah lingkungan

3.11 Memahami pentingnya tanah dan organisme yang hidup dalam tanah untuk keberlanjutan kehidupan melalui pengamatan

1) Fatwa MUI Nomor: 35 Tahun 2013 tentang Rekayasa Genetika dan Produknya, tanggal 3 Agustus 2013

2) Fatwa MUI Nomor: 01 Tahun 2013 tentang Penggunaan Mikroba dan Produk Mikrobial dalam Produk Pangan, tanggal 19 Januari 2010

Fatwa MUI Nomor: 22 tahun 2011

tentang Pertambangan Ramah

Lingkungan (tanggal 26 Mei 2011) 
Berdasarkan hasil analisis kesesuaian KD dengan dengan isu SSI yang merujuk fatwa MUI, terdapat beberapa KD yang tidak secara langsung berkaitan yaitu KD 3.2., 3.3., 3.4., 3.6., dan 3.7 (Kelas VII); KD 3.1., 3.2., 3.3., 3.5., 3.9. 3.13., 3.14., dan 3.15. (Kelas VIII); serta KD 3.1., 3.4., 3.5., 3.6., 3.7., dan 3.8. (Kelas IX). Meskipun demikian, penguasaan KD tersebut berkaitan dengan dasar pengetahuan yang harus dimiliki untuk membantu memecahkan permasalahan yang diajukan dalam pembelajaran IPA berbasis SSI.

\section{Kerangka Desain Implementasi Pembelajaran Berbasis SSI}

Pembelajaran berbasis Socio-Scientific Issues (SSI) merupakan perluasan dari pendekatan Science, Technology, and Society (STS) dan Problem-based approaches yang menempatkan konten sains pada konteks sosial untuk memberikan peserta didik suatu pandangan bagaimana sains berhubungan dengan dunia nyata (Zeidler et al., 2005). SSI melibatkan penggunaan topik ilmiah yang yang sengaja mengharuskan peserta didik untuk terlibat dalam dialog, diskusi, dan debat (Zeidler \& Nichols, 2009).

Sejumlah bidang telah diusulkan sebagai sumber Sosio-Scientific Issues yang potensial, termasuk perdebatan tentang tenaga nuklir, pemanasan global, pengujian genetik, penelitian sel, transplantasi, bio-fuel, dan lain sebagainya (McComas, 2014). Lebih meluas lagi, alternatif permasalahan global tersebut dapat dirujuk pada kajian Bybee yang telah mensurvey ilmuwan dan engineers untuk menunjukkan ranking permasalahan global. Didasarkan pada kajiannya, diperoleh beberapa permasalahan global (R. Bybee, 1984), yaitu:

1. Populasi dan pertumbuhan penduduk

2. Teknologi peperangan

3. Kelaparan dunia dan sumber makanan

4. Kualitas udara dan atmosfer

5. Sumber daya air

6. Penggunaan lahan

7. Krisis energi

8. Bahan berbahaya dan beracun
9. Kesehatan dan penyakit

10. Kepunahan flora dan fauna

11. Sumber daya mineral

12. Reaktor nuklir

Pandangan ajaran Islam tentang berbagai permasalahan global bisa jadi telah termuat - baik secara tersurat dan tersirat dalam sumber utama ajaran Islam, Al-Qur'an dan Hadis Nabi. Tidak tertutup pula kemungkinan bahwa hal-hal tersebut telah termuat dalam khazanah klasik karya para imam mazhab dan para ulama terdahulu, baik secara tegas atau pun dengan perumpamaan yang sesuai dengan kondisi dan perkembangan yang terjadi di masa lalu (Amin et al., 2015). Meskipun demikian, tidak semua orang dapat menelaah sumber ajaran Islam tersebut secara langsung, bahkan menjadi semakin kompleks jika mengenai permaslahan yang belum pernah dibicarakan sama sekali. Di sinilah peran Ulama sebagai penyambung lidah agama yang bertugas untuk mendekatkan jarak masa lalu dengan masa kini dengan mengkonstruksi kembali pemahaman khazanah Islam dengan cara yang lebih mengena dengan kondisi kekinian tanpa menyalahi ajaran agama Islam (Amin et al., 2015). Majelis Ulama Indonesia (MUI) hadir sebagai wadah musyawarah untuk menyelesaikan permasalahan sosial keagamaan yang dihadapi masyarakat melalui fatwa-fatwa yang diputuskan. Adapun proses dan mekanisme penetapan fatwa MUI dapat dilihat pada Gambar 1.

Rincian proses dan mekanisme sesuai Gambar 1. adalah sebagai berikut:

1. Pengkajian masalah. Dalam hal ini anggota Komisi harus terlebih dahulu memahami dengan jelas hakikat dan masalahnya. Jika masalahnya merupakan maslaah baru dan memerlukan penjelasan dari ahlinya, maka ahli yang bersangkutan didengarkan penjelasannya.

2. Setelah jelas permasalahannya, ditentukan apakah ia termasuk ke dalam kategori qat'iyat atau bukan. Jika termasuk qat'iyat, demikian juga jika telah ada ijma' 
mu'tabar, MUI menetapkan fatwa sebagaimana adanya. Jika tidak termasuk dalam kategori hukum qat'iyat, MUI selanjutnya melakukan ijtihad.

3. Dalam melakukan ijtihad, MUI dapat menempuh ijtihad insya' $i$ maupun

4. intiqa'i. Dalam hal ijtihad terakhir ini, MUI menggunakan pendekatan muqaranah al-maahib dan melakukannya secara jama'i (ijtihad jama'i).

Ulasan proses penetapan fatwa oleh MUI tersebut, menunjukkan suatu proses pengambilan keputusan dalam menyelesaikan suatu permasalahan dengan melibatkan berbagai macam sumber dan tahapan. Dalam hal ini, hasil dari putusan fatwa MUI dapat dijadikan sumber isu yang dapat diangkat dalam pembelajaran IPA berbasis SSI dengan menyesuaikan Kompetensi Dasar (KD) pada jenjang SMP/MTs. Pembelajaran berbasis SSI tersebut merupakan interaksi tiga komponen yang meliputi pendidik, peserta didik, serta konteks isu yang akan dicari penyelesaiannya. Hal tersebut diperlihatkan pada Gambar 2.

Konteks pada pembelajaran SSI berfungsi sebagai tema atau konsep pemersatu (unifying concept) beberapa Kompetensi Dasar (KD) yang harus dicapai oleh peserta didik. Konteks dapat memanfaatkan rujukan permasalahan yang berasal dari fatwa MUI. Adanya fatwa MUI menunjukkan bahwa terdapat urgensitas penyelesaian suatu masalah yang dihadapi masyarakat Muslim yang ada di Indonesia. Dalam hal ini, rujukan kasus fatwa MUI adalah kasus-kasus di bidang POM dan
IPTEK, serta bidang pelestarian lingkungan hidup.

Melalui konsep pemersatu tersebut, peserta didik dapat menghabiskan waktunya dalam mengkaji isu sosio-saintifik melalui berbagai sumber bacaan (termasuk pula AlQuran, sunnah, dan dalil-dalil mu'tabar), serta mengevaluasi konteks yang ada dari berbagai perspektif. Hal ini akan menjadi lebih efektif daripada peserta didik mengumpulkan berbagai macam informasi yang tidak saling terkait sehingga pada akhirnya menjadi menyesatkan (Zeidler \& Nichols, 2009). Konsekuensinya, pendidik juga harus menginvetasikan waktunya dalam menemukan sumber data dan perspektif ilmiah yang andal dan juga sebaliknya, perspektif yang berpotensi tidak masuk akal. Dengan demikian, peserta didik dapat dihadapkan pada berbagai macam bukti campuran, serta dapat belajar menilai validitas beragam klaim dan data. 


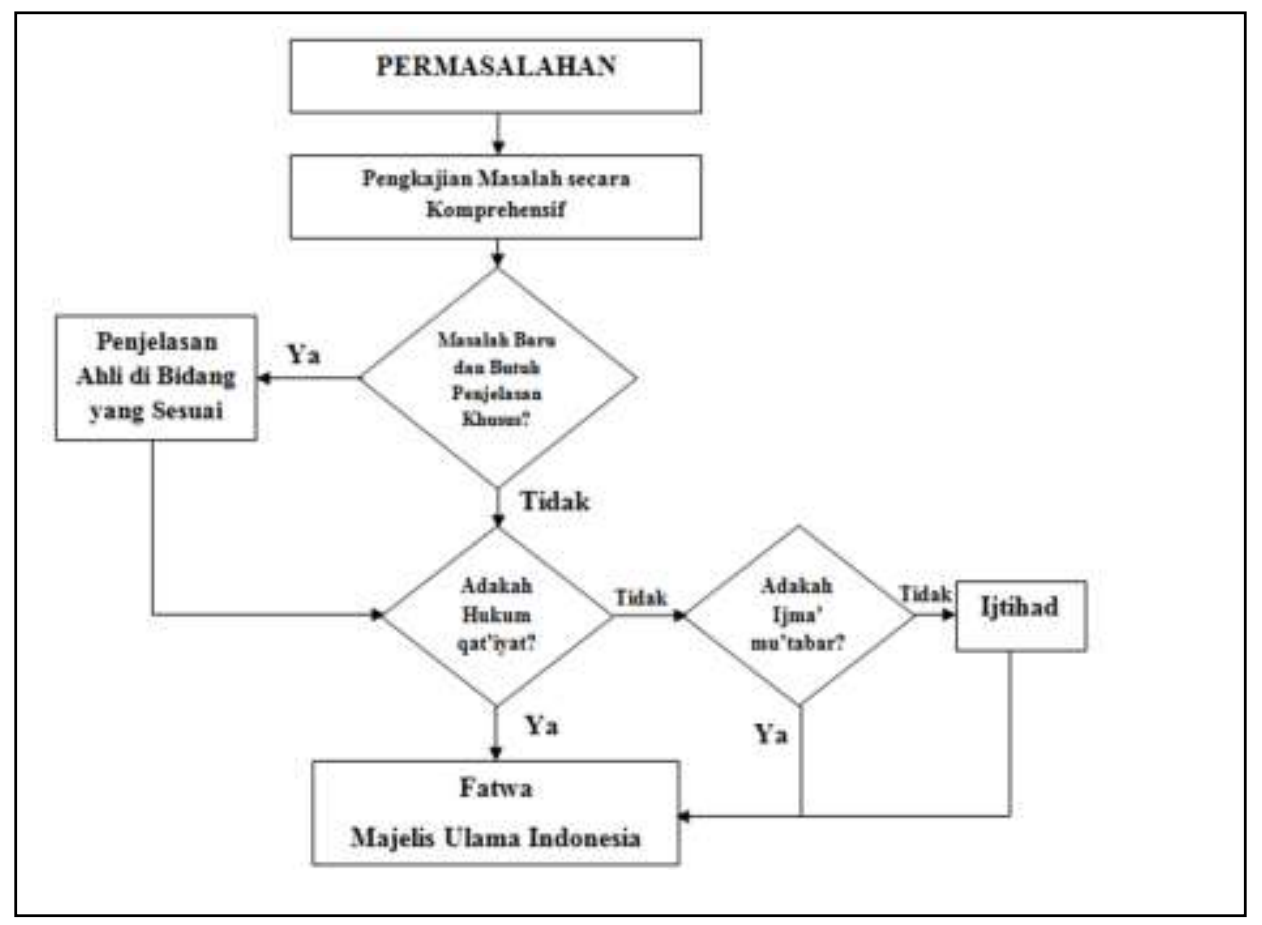

Gambar 1. Proses dan Mekanisme Penetapan Fatwa yang Dilakukan oleh MUI Sumber: Ilustrasi gambar didasarkan pada (Amin et al., 2015)

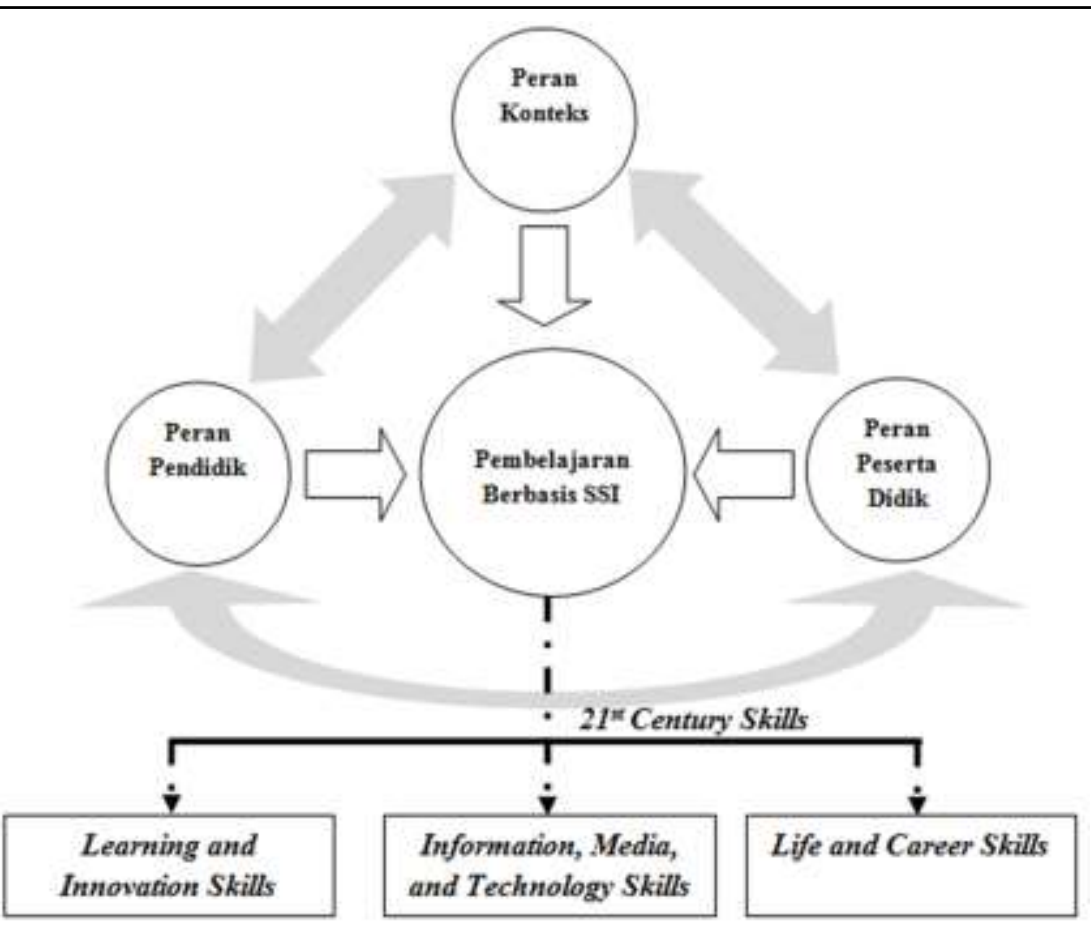

Gambar 2. Interaksi pada Pembelajaran Berbasis SSI untuk Mendorong Keterampilan Abad ke-21 
Dalam hal ini, pendidik tidak hanya sekedar menyusun bahan ajar dengan memberikan alternatif muatan isu tertentu, tetapi pendidik juga berperan mengekspose kemampuan peserta didik melalui kegiatan debat dan diskusi. IPA bukan sekedar menemukan dan menyajikan fakta, melainkan membangun argumen dan mempertimbangkannya, serta mendebat berbagai penjelasan tentang fenomena (McNeill, 2009). Oleh sebab itu ilmuwan menggunakan argumentasi untuk mendukung teori, model, dan menjelaskan tentang fakta alam (Erduran et al., 2006), sebagaimana pula yang dilakukan oleh para ulama dalam memberikan fatwa terhadap permasalahan masyarakat muslim. Hanya saja peranan argumentasi ini menurun dalam pendidikan IPA. Menurut Osborne, hanya 10\% guru sains yang menyajikan sains (atau IPA) sebagai sebuah pengetahuan yang diuji (dibuktikan dengan) proses pembuktian kebenarannya melalui penalaran konjektur, evaluasi bukti, dan mempertimbangkan argumen kontra. Kebanyakan pendidik IPA menyajikan sains sebagai fakta tanpa pertanyaan epistemik (Osborne, 2005). Pendidik IPA lebih menekankan pada "apa" yang harus dipercayai daripada "mengapa" harus dipercayai (Erduran, Ardac, \& Yakmaci-Guzel, 2006). Diskusi kelas merupakan cara yang dapat dilakukan untuk membentuk pembelajaran yang bersifat argumentatif. Diskusi kelas juga sangat efektif dalam mengkonstruksi pengetahuan, karena para pembelajar mengemukakan ideanya, bertanya, memberikan umpan balik, dan mengevaluasi ideanya (Cross, Taasoobshirazib, Hendricksc, \& Hickey, 2008).

Memindahkan konsep SSI dari teori menuju praktik sangatlah penting dalam menyajikan IPA di abad ke-21. Tantangan bagi pendidik dalam menyajikan pembelajaran berbasis SSI adalah membebaskan siswa dalam membangun sistem kepercayaan mereka sendiri dengan merumuskan perspektif baru terhadap permasalahan (Zeidler \& Nichols, 2009). Lebih lanjut, Zeidler \& Nichols memaparkan hambatan yang mungkin dihadapai peserta didik dalam pembelajaran berbasis SSI cenderung mencakup keyakinan moral (inti), kesalahpahaman ilmiah, kurangnya pengalaman pribadi, kurangnya pengetahuan konten, keterampilan penalaran ilmiah yang kurang dimanfaatkan, dan kedewasaan emosional. Meskipun demikian, hambatan tersebut perlu dihadapi untuk melatihkan keterampilan abad ke-21 (21 ${ }^{\text {st }}$ Century Skills) yang mencakup (1) keterampilan belajar dan berinovasi, (2) keterampilan informasi, media dan teknologi informasi, serta (3) keterampilan hidup dan karir.

Keterampilan belajar dan berinovasi akan membedakan antara peserta didik yang telah siap dan yang belum siap dalam menghadapi lingkungan hidup dan lingkungan kerja yang kompleks serta berkembang dengan pesatnya. Keterampilan ini meliputi keterampilan berkreasi dan berinovasi, keterampilan berpikir kritis dan pemecahan masalah, serta keterampilan berkomunikasi dan berkolaborasi. Selain keterampilan terebut, peserta didik juga perlu dibekali dengan keterampilan informasi, media, dan teknologi. Keterampilan ini menjadi begitu penting karena peserta didik hidup di lingkungan yang dikendalikan oleh teknologi dan media, ditandai oleh mudahnya mengakses informasi, perkembangan teknologi yang begitu ceat, serta kemampuan individu dalam berkolaborasi dan memberikan kontribusi yang belum dibayangkan sebelumnya. Peserta didik sebagai komponen masyarakat diharapkan mampu menunjukkan jangkauan pemikiran kritis dan fungsional yang meliputi literasi informasi, literasi media, serta literasi ICT (Information, Communications and Technology). Lebih lanjut, keterampilan hidup dan karir juga peting dibutuhkan oleh peserta didik. Hal itu dikarenakan lingkungan hidup dan kerja saat ini membutuhkan lebih dari sekedar keterampilan berpikir dan pengetahuan konten. Kemampuan untuk mengendalikan lingkungan hidup dan kerja yang kompleks dalam era persaingan informasi global menuntut peserta didik untuk 
mengembangkan kecakapan hidup dan karir, yang meliputi sikap fleksibel dan mudah beradaptasi (Flexibility and Adaptability), mampu berinisiatif dan menentukan arah sendiri (Initiative and Self-Direction), keterampilan sosial dan lintas budaya (Social and Cross-Cultural Skills), produktif dan dapat diperhitungkan (Productivity and Accountability), serta kepemimpinan dan tanggung jawab (Leadership and Responsibility) (Partnership for 21st Century Learning, 2015).

\section{Pembahasan}

Kurikulum 2013 yang sekarang dikenal dengan Kurikulum Nasional dirancang untuk memperkuat kompetensi siswa dari sisi pengetahuan, keterampilan dan sikap secara utuh. Proses pencapaian kompetensi dirancang melalui pembelajaran sejumlah mata pelajaran yang dirangkai sebagai suatu kesatuan yang saling mendukung pencapaian kompetensi tersebut. Bila pada jenjang SD/MI, semua mata pelajaran digabung menjadi satu dan disajikan dalam bentuk tema-tema, maka pada jenjang SMP/MTs pembelajaran sudah mulai dipisahkan menjadi mata pelajaran.

Sebagai transisi menuju ke pendidikan menengah, pemisahan ini masih belum dilakukan sepenuhnya bagi siswa SMP/MTs. Materi-materi dari bidang-bidang ilmu fisika, kimia, biologi, serta ilmu bumi dan antariksa masih perlu disajikan sebagai suatu kesatuan dalam mata pelajaran IPA (Ilmu Pengetahuan Alam). Hal ini dimaksudkan untuk memberikan wawasan yang utuh bagi siswa SMP/MTs tentang prinsip-prinsip dasar yang mengatur alam semesta beserta segenap isinya. Bidang ilmu Biologi dipakai sebagai landasan (platform) pembahasan bidang ilmu yang lain. Makhluk hidup digunakan sebagai obyek untuk menjelaskan prinsip-prinsip dasar yang mengatur alam seperti objek alam dan interaksinya, energi dan keseimbangannya, dan lain-lain (Kementerian Pendidikan dan Kebudayaan, 2017). Melalui pembahasan menggunakan bermacam bidang ilmu dalam rumpun ilmu pengetahuan alam, pemahaman utuh tentang alam yang dihuninya beserta benda-benda alam yang dijumpai di sekitarnya dapat dikuasai oleh peserta didik SMP/MTs.

Proses pembelajaran IPA SMP/MTs berdasarkan kurikulum nasional merupakan proses pembelajaran tematik integratif. Pembelajaran tematik merupakan pembelajaran dengan menggunakan tema-tema yang berfungsi sebagai pengait (the webbed model), sedangkan integratif merupakan pembelajaran IPA yang nampak jelas terintegrasi dalam kehidupan sehari-hari dan berhubungan dengan topik lain intra dan antar disiplin ilmu (the connected model). Tema-tema besar yang dipelajari di tingkat SMP, yaitu: materi, sistem, perubahan, dan interaksi. Tema besar tersebut dipelajari dalam topik-topik (Wisudawati \& Sulistyowati, 2014). Topik-topik yang diangkat dapat didasarkan pada isu-isu yang berhubungan dengan kajian fatwa MUI. Permasalahan dalam fatwa tersebut berfungsi sebagai konsep atau topik pemersatu beberapa kajian bidang ilmu termasuk ilmu agama. Adapun contoh tematik integratif dari pembelajaran IPA berbasis SSI yang berkenaan dengan fatwa MUI dapat diilustrasikan pada Gambar 3. 


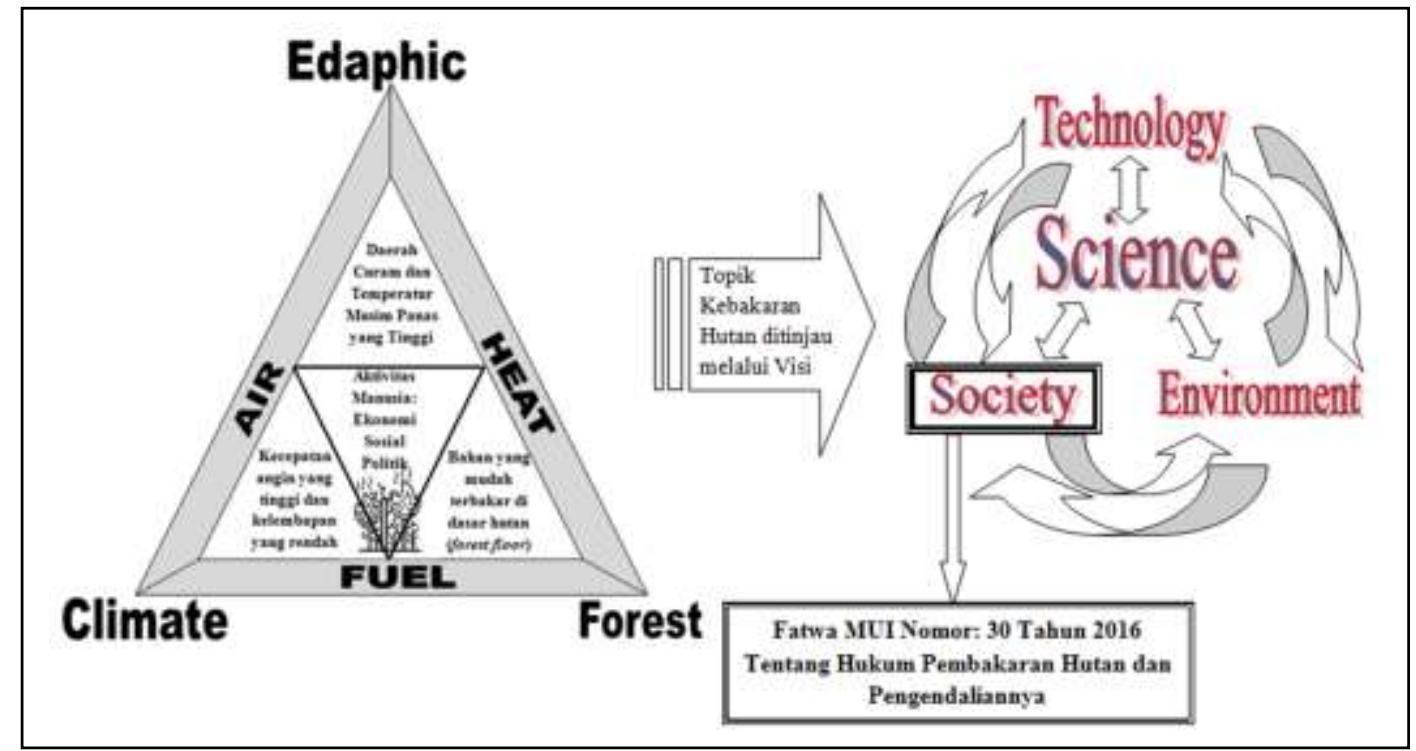

Gambar 3. Posisi Fatwa MUI pada Pembelajaran IPA berbasis Sosiosaintific-Issues mengenai Kebakaran Hutan

Pada Gambar 3. diterapkan visi dan pendekatan SETS (Science, Environment, Technology, and Society) pada pembelajaran berbasis SSI. Model pembelajaan bervisi SETS diinisiasi oleh adanya model pembelajaran STS (Science, Technology, Society) yang berkembang dengan penambahan nomenklatur environment atau lingkungan. Penambahan nomenklatur lingkungan dipengaruhi oleh perhatian manusia terhadap lingkungan yang ada di bumi yang sudah banyak mengalami perubahan, yang cenderung ke arah kerusakan lingkungan akibat teknologi yang dikembangkan oleh manusia. Visi SETS diturunkan dengan landasan filosofis yang mencerminkan kesatuan antara unsur SETS dengan mengingat unsur-unsur SETS dalam akronim tersebut dan aplikasi dalam konteks pendidikan (Binadja, 2005, p. 2). Pola integrasi menunjukkan integrated learning di mana terjadi integrasi intradisipliner bidang keilmuan IPA sebagaimana terlihat pada Gambar 4., serta intrerdisipliner yang meliputi ilmu sosial, ekonomi, budaya, dan agama. Kajian tematik "Kebakaran Hutan" menempatkan aspek lingkungan (Environment) pada posisi pusat untuk di analisis konsep sains yang ada, serta aspek teknologi yang memungkinkan untuk pengendaliannya. Konsep sains yang ada dapat mencakup Kompetensi Dasar kelas VII dengan kode 3.7., 3.8., 3.9., dan 3.10. 


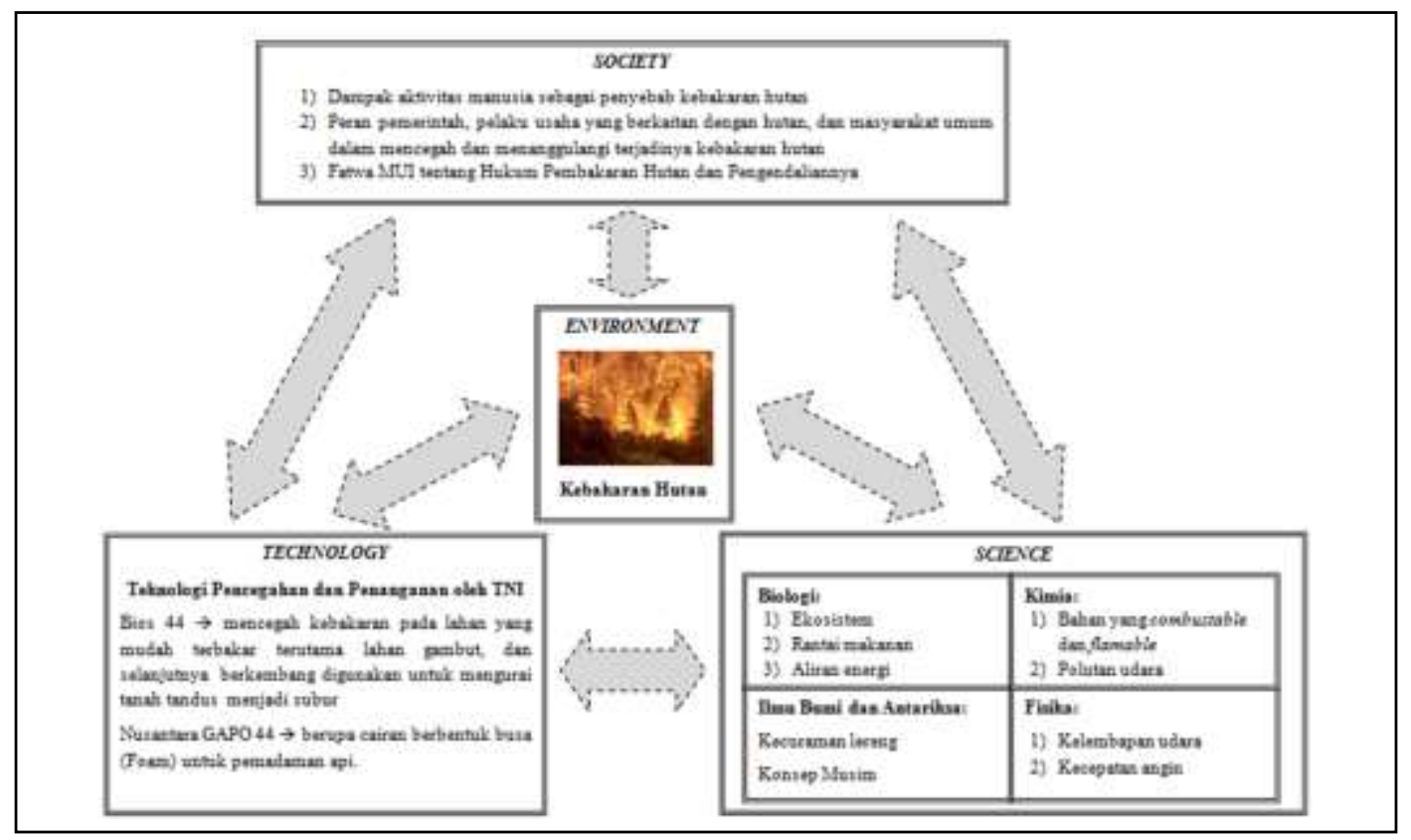

Gambar 4. Tema "Kebakaran Hutan" sebagai Tema Sentra untuk Pembelajaran Berbasis SSI dengan visi SETS

Pada Gambar 4. cara pandang tentang kasus "Kebakaran Hutan" dilihat pula dari aspek teknologi. Aspek teknologi yang dikaji sebagai alternatif pencegahan kebakaran adalah cairan Bios 44, serta teknologi penanganan kebakaran adalah Nusantara GAPO 44. Keduanya adalah teknologi yang dikembangkan oleh Korem 044/Gapo TNI AD. Cara kerja BIOS 44 yang merupakan jenis perpaduan beberapa mikroorganisme yang disatukan, berfungsi untuk memperkecil hingga menutupi rongga-rongga yang ada lahan gambut dalam tempo tertentu, dan nantinya lahan gambut tersebut tidak akan mudah terbakar. Adapaun Nusantara GAPO 44 berupa cairan berbentuk busa (foam) untuk pemadaman api (Dinas Penerangan Angkatan Darat, 2016).

Kebakaran hutan dipengaruhi oleh faktor udara (air), panas (heat), dan komponen yang menjadi bahan bakar (fuel). Ditinjau dari aspek sains, faktor edaphic adalah faktor abiotik yang berhubungan dengan komposisi fisika dan kimia dari dasar tanah pada area tertentu. Sebagai contoh, tanah yang sangat basa mungkin merupakan faktor edaphic yang membatasi variasi tanaman yang bisa tumbuh di suatu region. Pada kasus kebakaran hutan, faktor edaphic yang dikaji berkaitan dengan kecuraman lokasi, serta temperatur musim panas yan tinggi. Konsep fisika dapat didiskusikan terkait dengan kelembaban udara serta kecepatan angin. Aspek kimia diulas kaitannya dengan komposisi material yang mudah terbakar dan menyala yang mungkin ada di kawasan lantai dasar hutan. Biologi hutan diulas terkait dengan konsep ekosistem, rantai makanan, dan aliran energi. Selain aspek sains, komponen society pada visi SETS melihat dampak aktivitas manusia terhadap hutan, serta peran pemerintah, pelaku usaha, dan masyarakat berkaitan dengan pelestarian hutan dan penanganan kebakaran hutan. Pada aspek ini, Fatwa MUI (tentang Hukum Pembakaran Hutan dan Pengendaliannya) menjadi salah satu solusi dalam kehidupan masyarakat muslim yang dapat dikaji lebih lanjut dalam pembelajaran.

$$
\text { Model pembelajaran terpadu }
$$
(integrated model) memiliki karakteristik yaitu dimulai dengan identifikasi konsep, keterampilan, sikap yang overlap pada 
beberapa disiplin ilmu atau beberapa bidang studi dengan tema yang berfungsi sebagai konteks pembelajaran (Wisudawati \& Sulistyowati, 2014). Dengan model ini, peserta didik akan lebih memahami bagaimana hubungan antar bidang studi melalui kegiatan pembelajaran. Pada pelaksanaanya model ini menuntut wawasan yang luas dari pendidik, serta sering terjadi hanya fokus pada proses membelajarkan dan diskusi pada konteks atau isu yang ada sehingga target penguasaan konsep tidak terlalu diperhatikan. Meskipun demikian, model pembelajaran integrated atau terpadu menjadi penting untuk diterapkan kaitannya dengan keterampila abad ke-21 yang diharapakan dapat dimiliki oleh peserta didik. Orientasi aktivitas pembelajaran memberikan peluang bagi peserta didik untuk menunjukkan keterampilan abad ke-21 melalui proses pemecahan isu-isu sosio-saintifik yang diajukan dalam pembelajaran, sebagaimana ditampilkan pada Tabel 4.

Tabel 4 Orientasi aktivitas peserta didik dalam menumbuhkan Keterampilan Abad ke-21 (2 $1^{\text {st }}$ Century Skills)

\begin{tabular}{|c|c|c|}
\hline $\begin{array}{l}\text { Keterampilan Abad ke- } \\
21\end{array}$ & $\begin{array}{l}\text { Sub Komponen } \\
\text { Keterampilan }\end{array}$ & Alternatif Orientasi Aktivitas Peserta Didik \\
\hline \multirow[t]{3}{*}{$\begin{array}{l}\text { Keterampilan belajar } \\
\text { dan berinovasi }\end{array}$} & $\begin{array}{l}\text { Keterampilan berkreasi dan } \\
\text { berinovasi }\end{array}$ & $\begin{array}{l}\text { Proyek dalam merancang inovasi teknologi } \\
\text { pencegahan dan penanganan kebakaran skala rumah } \\
\text { tangga. Sebagai contoh, merancang rumah siap } \\
\text { bencana (kebakaran) dengan meninjau aspek } \\
\text { material, desain, dan posisi komponen interior. }\end{array}$ \\
\hline & $\begin{array}{l}\text { Keterampilan berpikir kritis } \\
\text { dan pemecahan masalah }\end{array}$ & $\begin{array}{l}\text { Disajikan berbagai data terkait dengan data } \\
\text { kebakaran hutan di Indonesia, dilakukan diskusi dan } \\
\text { telaah terkait dengan faktor-faktor penyebab, serta } \\
\text { aspek pencegahan dan penanganannya. }\end{array}$ \\
\hline & $\begin{array}{l}\text { Keterampilan berkomunikasi } \\
\text { dan berkolaborasi }\end{array}$ & $\begin{array}{l}\text { Aktivitas kolaborasi dan berkomunikasi melalui } \\
\text { kegiatan role playing atau bermain peran dalam } \\
\text { memberikan gambaran utuh tentang kasus } \\
\text { kebakaran hutan. }\end{array}$ \\
\hline \multirow{3}{*}{$\begin{array}{l}\text { Keterampilan } \\
\text { informasi, media, dan } \\
\text { teknologi }\end{array}$} & Literasi informasi & $\begin{array}{l}\text { Melakukan validasi dan meng-up date informasi } \\
\text { terkait data statistika kebakaran hutan di Indonesia. }\end{array}$ \\
\hline & Literasi media & $\begin{array}{l}\text { Mencari sumber dari berbagai media, termasuk } \\
\text { mengkaji Al-qur'an, Hadis, fatwa MUI berkenaan } \\
\text { dengan pelestarian lingkungan hidup }\end{array}$ \\
\hline & $\begin{array}{l}\text { Literasi ICT (Information, } \\
\text { Communications and } \\
\text { Technology) }\end{array}$ & $\begin{array}{l}\text { Mengoptimalkan penguasaan keterampilan } \\
\text { pemerolehan data dan informasi melalui jejaring } \\
\text { internet, serta mempublikasikan hasil yang } \\
\text { diperoleh terkait dengan pemecahan masalah } \\
\text { kebakaran hutan melalui jalur online }\end{array}$ \\
\hline \multirow[t]{4}{*}{$\begin{array}{l}\text { Keterampilan hidup } \\
\text { dan karir }\end{array}$} & $\begin{array}{l}\text { Sikap fleksibel dan mudah } \\
\text { beradaptasi (Flexibility and } \\
\text { Adaptability) }\end{array}$ & $\begin{array}{l}\text { Menunjukkan sikap fleksibel dan mudah } \\
\text { beradaptasi melalui aktivitas diskusi kelompok. }\end{array}$ \\
\hline & $\begin{array}{l}\text { Berinisiatif dan menentukan } \\
\text { arah sendiri (Initiative and } \\
\text { Self-Direction) }\end{array}$ & $\begin{array}{l}\text { Mampu secara mandiri dalam menyusun time line } \\
\text { dalam pengerjaan proyek berbasis SSI. }\end{array}$ \\
\hline & $\begin{array}{l}\text { Keterampilan sosial dan } \\
\text { lintas budaya (Social and } \\
\text { Cross-Cultural Skills) }\end{array}$ & $\begin{array}{l}\text { Mencoba mengkaji budaya dalam pelestarian } \\
\text { lingkungan atau hutan di berbagai kawasan di } \\
\text { Indonesia, bahkan dunia. }\end{array}$ \\
\hline & $\begin{array}{l}\text { Produktivitas dan dapat } \\
\text { diperhitungkan (Productivity } \\
\text { and Accountability) }\end{array}$ & $\begin{array}{l}\text { Menunjukkan usulan-usulan dan pendapat yang } \\
\text { berkualitas kaitannya dengan pemecahan masalah. }\end{array}$ \\
\hline
\end{tabular}




\begin{tabular}{ll}
\hline $\begin{array}{l}\text { Kepemimpinan dan } \\
\text { tanggung jawab (Leadership } \\
\text { and Responsibility) }\end{array}$ & $\begin{array}{l}\text { Memliki inisiatif dalam memulai proyek dan diskusi } \\
\text { berkenaan pemecahan masalah kebakaran hutan. }\end{array}$ \\
\end{tabular}

Kegiatan pembelajaran berbasis SSI pada akhirnya menempatkan fatwa MUI pada area sudut pandang society dalam visi SETS yang diterapkan. Kegitan pembelajaran yang memadukan berbagai bidang ilmu ini diharapkan mampu mengoptimalkan pemerolehan keterampilan abad ke-21 peserta didik. Kajian penelitian selanjutnya diharapkan dapat menurunkan hasil kerangka desain pembelajaran berbasis SSI dalam bentuk perencanaan pembelajaran pada masing-masing kompetensi dasar, aplikasinya dalam penelitian kelas, serta merancang dan mengembangkan instrumen evaluasi berbasis SSI dengan mengintegrasikan nilai-nilai islam yang salah satunya terwujud dalam media fatwa MUI.

\section{Simpulan}

Pembelajaran berbasis Socio-Scientific Issues (SSI) merupakan perluasan dari pendekatan Science, Technology, and Society (STS) dan Problem-based approaches yang menempatkan konten sains pada konteks sosial untuk memberikan peserta didik suatu pandangan bagaimana sains berhubungan dengan dunia nyata. Konteks sosial yang diangkat dapat didasarkan pada isu-isu yang berhubungan dengan kajian fatwa MUI. Permasalahan dalam fatwa tersebut berfungsi sebagai konsep atau topik pemersatu beberapa kajian bidang ilmu termasuk ilmu agama. Hasil analisis kesesuaian Kompetensi Dasar (KD) dengan dengan isu SSI yang merujuk fatwa MUI, terdapat beberapa KD yang tidak secara langsung berkaitan yaitu KD 3.2., 3.3., 3.4., 3.6., dan 3.7 (Kelas VII); KD 3.1., 3.2., 3.3., 3.5., 3.9. 3.13., 3.14., dan 3.15. (Kelas VIII); serta KD 3.1., 3.4., 3.5., 3.6., 3.7., dan 3.8. (Kelas IX). Meskipun demikian, penguasaan KD tersebut berkaitan dengan dasar pengetahuan yang harus dimiliki untuk membantu memecahkan permasalahan yang diajukan dalam pembelajaran IPA berbasis SSI.

Model pembelajaran bervisi SETS dapat dijadikan alternatif dalam mendesain pembelajaran berbasis SSI dengan konteks masalah yang ada pada fatwa MUI. Pola integrasi menunjukkan model pembelajaran terpadu (integrated learning) di mana terjadi integrasi intradisipliner bidang keilmuan IPA (yang meliputi biologi, kimia, fisika, serta ilmu pengetahuan bumi dan antariksa), serta intrerdisipliner yang meliputi ilmu sosial, ekonomi, budaya, dan agama. Dengan model ini, peserta didik akan lebih memahami bagaimana hubungan antar bidang studi melalui kegiatan pembelajaran. Integrated learning menjadi penting untuk diterapkan kaitannya dengan pemerolehan keterampilan abad ke-21 yang meliputi (1) keterampilan belajar dan berinovasi, (2) keterampilan informasi, media dan teknologi informasi, serta (3) keterampilan hidup dan karir.

\section{Saran}

Hasil paparan ini memberikan konsekuensi untuk merubah paradigma pendidik dalam membelajarkan IPA ke arah pembelajaran yang terpadu. Keterpaduan tersebut tidak hanya dalam satu bidang keilmuan IPA, tetapi interdisipliner. Dengan demikian, pendidik diharapkan dapat memperluas wawasannya di berbagai bidang kajian ilmu dengan membawa bekal IPA sebagai pusat keilmuannya. Selain itu, sumber Al-Qur'an dan Hadis, serta sumber lainnya berkenaan dengan nilai-nilai Islami semisal pemikiran-pemikiaran ulama dapat diinternalisasikan dalam pembelajaran IPA. Pembelajaran IPA dalam kerangka "Ayo Belajar IPA dari Ulama" memberikan arah pada proses Islamisasi ilmu pengetahuan tidak 
hanya pada area ilmu alam, tetapi juga ilmu sosial.

Penelitian lanjutan berkenaan dengan perencanaan pembelajaran pada masing-masing kompetensi dasar, aplikasinya dalam penelitian kelas, serta merancang dan mengembangkan instrumen evaluasi berbasis SSI dengan mengintegrasikan media fatwa MUI diharapkan dapat dilaksanakan. Penelitian akan mengarah pada pembekalan keterampilan abad ke- 21 bagi peserta didik, serta reintegrasi keilmuan yang merujuk pada islamisasi sains.

\section{Referensi}

Amin, M., Sam, M. I., Sa'adi, Z. T., Hasanuddin, H., Hasanudin, H., \& Sholeh, M. A. N. (2015). Himpunan Fatwa MUI Bidang POM dan IPTEK. (F. Mutiara, $\mathrm{H}$. Saputra, \& A. Prasetya, Eds.). Jakarta: Erlangga.

Anagün, Ş. S., \& Özden, M. (2010). Teacher candidate's perceptions regarding socioscientific issues and their competencies in using socio-scientific issues in science and technology instruction. Procedia Social and Behavioral Sciences, 9, 981-985. https://doi.org/10.1016/j.sbspro.2010.12. 271

Badan Penelitian dan Pengembangan, K. P. dan K. (2013). Kompetensi Dasar Sekolah Menengah Pertama (SMP)/ Madrasah Tsanawiyah (MTs). Jakarta: Kementrian Pendidikan dan Kebudayaan.

Binadja, A. (2005). Pedoman Pengembangan Silabus Pembelajaran Berdasar Kurikulum 2004 Bervisi dan Berpendekatan SETS (Science, Environment, Technology, Society) atau (Sains, Lingkungan, Teknologi, dan Masyarakat). Semarang: Laboratorium SETS Unnes Semarang.

Bybee, R. (1984). Global Problems and Science Education Policy. In R. W. Bybee, J. Carlson, \& A. J. McCormack (Eds.), Redesigning Science and Technology Education. Washington, D.C.: National Science Teachers Association.

Cross, D., Taasoobshirazib, G., Hendricksc, S.,
\& Hickey, D. T. (2008). Argumentation: A strategy for improving achievement and revealing scientific identities. International Journal of Science Education, 30(6), 837-861. https://doi.org/10.1080/09500690701411 567

Dinas Penerangan Angkatan Darat, T. N. I. (2016). Bios 44 Dan Nusantara Gapo 44, Teknologi Untuk Restorasi Gambut. Retrieved from https://tniad.mil.id/2016/09/bios-44-dannusantara-gapo-44-teknologi-untukrestorasi-gambut-2/

Erduran, S., Ardac, D., \& Yakmaci-Guzel, B. (2006). Learning to teach argumentation: Case studies of pre-service secondary science teachers. Eurasia Journal of Mathematics, Science and Technology Education, 2(2), 1-14.

Golshani, M. (2004). Issues in Islam and Science. Tehran: Institute for Humanities and Cultural Studies.

Jasin, M. (2013). Ilmu Alamiah Dasar. (M. Ibrahim \& M. T. Hidayat, Eds.) (20th ed.). Jakarta: PT Rajagrafindo Persada.

Kang, M. hee, Heo, H., Jo, I. H., Shin, J., \& Seo, J. (2010). Developing an educational performance indicator for new millennium learners. Journal of Research on Technology in Education, 43(2), 157170.

https://doi.org/10.1080/15391523.2010.1 0782567

Kementerian Pendidikan dan Kebudayaan. (2017). Buku Guru Ilmu Pengetahuan Alam. Jakarta: Kementerian Pendidikan dan Kebudayaan.

Louis, R. C. (2012). A Case Study Exploring Technology Integration and Incorporation of 21st Century Skills in Elementary Classrooms. Boston, Massachusetts.

McComas, W. (2014). Socio-scientific Issuebased Instruction. In W. F.McComas (Ed.), The Language of Science Education: An Expand Glossary of Key Terms and Concepts in Science Teaching and Language (p. 100). Sense Publishers. https://doi.org/10.4324/9780203597125 
McNeill, K. L. (2009). Teachers' use of curriculum to support students in writing scientific arguments to explain phenomena. Science Education, 93(2), 233-268.

https://doi.org/10.1002/sce.20294

National Science Teachers Association. (2003). Standards for science teacher preparation.

Nuangchalerm, P. (2009). Development of Socioscientific Issues-Based Teaching for Preservice Science Teachers. Journal of Social Sciences, 5(3), 239-243.

Osborne, J. (2005). The Role of Argument in Science Education. In K. Boersma, M. Goedhart, O. De Jong, \& H. Eijkelhof (Eds.), Research And The Quality of Science Education (pp. 367-380). Dordrecht: Springer. Retrieved from www.springeronline.com

Partnership for 21st Century Learning. (2015). P21 Framework Defintion. Partnership for 21st Century Learning. Washington, D.C.: The Partneship for 21st Century Learning. Retrieved from http://www.p21.org/documents/P21_Fra mework_Definitions.pdf

Topcu, M. S., Sadler, T. D., \& Yilmaz-Tuzun, O. (2010). Preservice Science Teachers' Informal Reasoning about Socioscientific Issues: The influence of issue context. International Journal of Science Education, 32(18), 2475-2495.

Wisudawati, A. W., \& Sulistyowati, E. (2014). Metodologi Pembelajaran IPA. Yogyakarta: Bumi Aksara.

Zeidler, D. L., \& Nichols, B. H. (2009). Socioscientific issues: Theory and practice. Journal of Elementary Science Education, 21(2), 49-58. https://doi.org/10.1007/BF03173684

Zeidler, D. L., Sadler, T. D., Simmons, M. L., \& Howes, E. V. (2005). Beyond STS: A Research-based Framework for Socioscientific Issues Education. Science Education, 89(3), 357-377. https://doi.org/10.1002/sce.20048 